\title{
IMPROVING PHYSICOCHEMICAL CHARACTERISTIC AND PALATABILITY OF KING GRASS (Pennisetum hybrid) SILAGE BY INOCULATION OF Lactobacillus plantarum - Saccharomyces cerevisiae CONSORTIA AND ADDITION OF RICE BRAN
}

\section{PENINGKATAN KUALITAS FISIKO-KIMIA DAN PALATABILITAS SILASE RUMPUT RAJA (Pennisetum hybrid) YANG DIBERI PERLAKUAN INOKULUM Lactobacillus plantarum - Saccharomyces cerevisiae DAN PENAMBAHAN DEDAK PADI}

\author{
Ahmad Sofyan ${ }^{1 *}$, Yantyati Widyastuti ${ }^{2}$, Ristianto Utomo ${ }^{3}$, and Lies Mira Yusiati ${ }^{3}$ \\ ${ }^{1}$ Laboratory of Bio-Feed Additive Technology, Research Unit for Natural Product Technology (BPTBA), \\ Indonesian Institute of Sciences (LIPI), Yogyakarta, 55861 \\ ${ }^{2}$ Research Center for Biotechnology, Indonesian Institute of Sciences (LIPI), Cibinong, 16911 \\ ${ }^{3}$ Faculty of Animal Sciences, Universitas Gadjah Mada, Yogyakarta, 55281
}

Submitted: 15 September 2016, Accepted: 30 January 2017

\begin{abstract}
This study was conducted to determine the effectiveness of inoculants consisted of lactic acid bacteria Lactobacillus plantarum (Lp) and yeast Saccharomyces cerevisiae (Sc) combined with the addition of rice bran on the physicochemical characteristics and palatability of king grass (Pennisetum hybrid) silage. The experiment was arranged in the randomized factorial design (3x3) consisting of the inoculants treatments (control, $L p, L p+S c)$ and the different level of rice bran addition $(0,5$ and $10 \%)$ which contained 3 replications in each treatment. The measured variables were physicochemical characteristics i.e. color, odor, $\mathrm{pH}$, lactic acid, Fleigh points (quality indication score), and palatability of silage. Inoculation of Lp and $\mathrm{Lp}+\mathrm{Sc}$ improved silage odor and reduced fungal contamination. Silage treated by $\mathrm{Lp}+\mathrm{Sc}$ and rice bran (5$10 \%)$ resulted in low $\mathrm{pH}$ and high lactic acid concentration and Fleigh points significantly $(P<0.05)$. However, the interaction between inoculants and rice bran treatment was not significance $(P>0.05)$. Either inoculation or addition of rice bran tended to enhance the palatability of silage in cattle. It concluded that the addition of inoculants $L$. plantarum and S. cerevisiae with/without the addition of 5-10\% rice bran could improve the physicochemical characteristics of silage and its palatability to cattle.
\end{abstract}

(Keywords: King grass, L. plantarum, Palatability, S. cerevisiae, Silage)

\section{INTISARI}

Penelitian ini bertujuan untuk mengetahui efektivitas penambahan inokulum bakteri asam laktat Lactobacillus plantarum (Lp) dan khamir Saccharomyces cerevisiae (Sc) dengan level penambahan dedak padi terhadap karakteristik fisika, kimia dan palatabilitas pada silase rumput raja (Pennisetum hybrid). Perlakuan dirancang dengan Rancangan Acak Lengkap Pola Faktorial (3x3) dengan faktor perlakuan jenis inokulum (kontrol, Lp, Lp+Sc) dan perbedaan penambahan dedak padi (0, 5 dan 10\%) serta masing-masing perlakuan mempunyai 3 ulangan. Peubah yang diamati terdiri dari karakteristik fisik-kimia (warna, aroma, $\mathrm{pH}$, asam laktat dan nilai Fleigh) dan tingkat palatabilitas silase. Hasil penelitian menunjukkan bahwa perlakuan inokulum memperbaiki aroma silase dan menurunkan kontaminasi jamur. Silase yang diberi perlakuan $\mathrm{Lp}+\mathrm{Sc}$ dan penambahan dedak padi (5-10\%) memiliki $\mathrm{pH}$ terendah seiring dengan peningkatan kadar asam laktat dan nilai Fleigh secara signifikan $(P<0,05)$. Namun, tidak terdapat interaksi yang nyata $(P>0,05)$ antara perlakuan inokulum dan penambahan dedak padi terhadap kualitas silase. Silase dengan perlakuan inokulum atau penambahan dedak padi menunjukkan tingkat palatabilitas yang lebih tinggi terhadap ternak sapi. Penelitian ini dapat disimpulkan bahwa penambahan inokulum L. plantarum dan S. cerevisiae dan/atau penambahan dedak padi 5-10\% mampu memperbaiki karakteristik fisik-kimia silase serta tingkat palatabilitasnya untuk ternak sapi.

(Kata kunci: L. plantarum, Palatability, Rumput Raja, S. cerevisiae, Silase)

\footnotetext{
${ }^{*}$ Korespondensi (corresponding author):

Telp. +62-274-392570 / 391168

E-mail: sofyan_lipi@yahoo.co.id
} 


\section{Introduction}

The main factor leads to lower productivity in ruminant is a limited number of fresh forage, especially during the dry season (in the tropics) and winter (in the sub-tropics). Production of forage such as King grass (Pennisetum hybrid) reaches around 150-160 tons per hectare annually (ICAR, 2010). King grass is easy to grow in the low- or highlands, and its production is higher than the elephant grass (Pennisetum purpureum) (Budiman and Djamal, 1994). Low production of forage in the dry season had implications for declining availability of forage to supply animal feeds. Implementation of preservation technology by making silage could be achieved to ensure the availability of forage continuously. Although ensilage are developing continually, this technology has not been widely applied in the small-holder farmers. Implementation of the ensilage technology is facing with some limitations as follows; availability of ensilage equipment, lack of farmers knowledge to adopt the technology, and high levels of rotten silage due to the failure of anaerobic conditions.

The principle of making silage is to achieve anaerobic conditions and suppress the growth of undesirable microorganisms such as Clostridia and Enterobacteria (McDonald et al., 1991). Maintaining quality of silage by the addition of inoculant and soluble carbohydrate fraction were conducted to optimize the production of lactic acid and minimize the nutrient lost of forage during ensilage (Tabacco et al., 2011; Amer et al., 2012). Lactic acid bacteria (LAB) are common inoculant that serves to convert soluble carbohydrates into organic acids or lactic acid. Lactobacillus plantarum is one of LAB species which can be isolated from forage such as maize and tropical grasses (Zhang et al., 2000; Santos et al., 2013).

Producing lactic acid by $\mathrm{LAB}$ can be constrained by the presence of oxygen during ensilage. These are caused by optimum density, and anaerobic conditions in silage could not be achieved when raw materials were filled in a silo. Efforts to improve the anaerobic condition is necessary so that the silage quality can be maintained. An effort may be performed to increase anaerobic conditions in the silage by adding Saccharomyces cerevisiae as an aerobic fungi. Residual oxygen in silage was possibly utilized by $S$. cerevisiae. The presence of $S$. cerevisiae in a growth medium of LAB showed no antagonist reaction because the metabolic activity of $S$. cerevisiae supports the growth of LAB (Gobbetti et al., 1998; Sofyan et al., $2011 b)$. In a recent study, the addition of $S$. cerevisiae on silage had the potential to support the growth of LAB which had been used as a silage inoculant (Duniere et al., 2015).

Improving silage quality by the addition of inoculant was suggested to give positive response in animal acceptability and digestibility. Therefore, the study of the use of $S$. cerevisiae and its interaction with the lactic acid bacteria as a silage inoculant needs to be conducted. This experiment was performed to evaluate the effect of $L$. plantarum (Lp) and $S$. cerevisiae (Sc) inoculant consortia with the different level addition of rice bran on the physicochemical characteristics and palatability of king grass silage.

\section{Materials and Methods}

\section{Preparation of forage and inoculant}

King grass (Pennisetum hybrid) was harvested at $60 \mathrm{~d}$, which was planted in the forage collection field of the Research Unit for Natural Product Technology (BPTBA), the Indonesian Institute of Sciences (LIPI) in Yogyakarta. Inoculant consortia were used in this experiment consisting of $L$. plantarum and $S$. cerevisiae that had been isolated in the previous study (Sofyan et al., 2011b). Those isolates were grown on MRSB (deMann Rogossa Sharpe Broth, Oxoid ${ }^{\circledR}$ ) and MEB (Malt Extract Broth, Merck ${ }^{\circledR}$ ) for L. plantarum and $S$. cerevisiae, respectively. A total colony of $L$. plantarum and $S$. cerevisiae on each medium accounted for $10^{8} \mathrm{CFU} / \mathrm{mL}$ and $10^{7}$ CFU/mL, respectively.

\section{Inoculant treatment in silage}

The effectiveness of inoculants on silage characteristic was treated by addition of inoculants in combination with rice bran as water soluble carbohydrate source (WSC). The experiment was arranged in randomized factorial design $(3 \times 3)$ consisting of inoculants treatments (a type of inoculants; control, Lp, $\mathrm{Lp}+\mathrm{Sc}$ ) and different level of rice bran addition (level; 0, 5 and 10\%). Each treatment consisted of three replications was described in Table 1. Inoculant consortia was a combination of $L$. plantarum and $S$. cerevisiae $(3: 1 \mathrm{v} / \mathrm{v})$ which was optimized in the 
Table 1. Inoculant treatment and rice bran addition in king grass silage

\begin{tabular}{lccc}
\hline \multicolumn{1}{c}{ Inoculants } & \multicolumn{3}{c}{ Level of rice bran addition (\% WSC) } \\
\cline { 2 - 4 }$($ CFU/g sample) & $0 \%(0 \%)$ & $5 \%(0.27 \%)$ & $10 \%(0.54 \%)$ \\
\hline Without Inoculant (A) & $\mathrm{A} 0$ & $\mathrm{~A} 5$ & $\mathrm{~A} 10$ \\
$\mathrm{Lp}(\mathrm{B})\left(10^{6} \mathrm{cfu} / \mathrm{g}\right)$ & $\mathrm{B} 0$ & $\mathrm{~B} 5$ & $\mathrm{~B} 10$ \\
$\mathrm{Lp}+\mathrm{Sc}(\mathrm{C})\left(10^{6} \mathrm{cfu} / \mathrm{g}[\mathrm{Lp}]+10^{5} \mathrm{cfu} / \mathrm{g}[\mathrm{Sc}]\right)$ & $\mathrm{C} 0$ & $\mathrm{C} 5$ & $\mathrm{C} 10$ \\
\hline
\end{tabular}

Lp (L. plantarum), Sc (S. cerevisiae), each treatment contained 3 replications. * \% WSC was estimated by calculation of WSC content in rice bran (Despal et al., 2011).

previous study (Sofyan et al., 2011a). The inoculation dosage was $1 \mathrm{ml}$ in $100 \mathrm{~g}$ of silage. The procedure of making silage consisted of several stages was; 1 ) preparing raw materials, 2) mixing (According to the appropriate treatment), 3) packaging and incubation (Figure 1). Prior to mixing with concentrate, king grass was chopped by the self-modified chopper in 1-3 cm length. Fresh sample of king grass ( $D M= \pm 20 \%$ ) was wilted for 24 hours (DM = $\pm 28 \%$ ) in room temperature to increase the dry matter.

The addition of inoculant $1 \%(\mathrm{v} / \mathrm{w})$ and water was performed to adjust moisture content (approximately 75\%) in ensilage mixture. After the ingredients mixed homogeneously, the mixtured silage was packed in a plastic bag (5 kg / pack) and incubated for 21 days at room temperature anaerobically. To achieve anaerobe condition, the remained air in silage was manually pushed and strengthfully tied by a rubber belt.

\section{Physical assessment of the silage}

Texture and flavor of silage were evaluated at the last incubation ( $21 \mathrm{~d})$. Briefly, silage bag was opened and immediately observed. Three person of the expert panelists were previously trained in making silage to asses and evaluate texture and flavor of silage. Level of silage flavor was quantified by a scoring methods as was described; off-flavor (score: 0), less fragrant (score: 1), medium fragrant (score:2), and heavy fragrant (score: 3 ). Observations level of fungal contamination in silage was conducted by observing at the presence of mold. Estimated level of fungal contamination (LFC) percentage on the surface area with categories i.e. no contamination $(0 \%)$, mild $(<5 \%)$, medium $(5-15 \%)$, and severe $(>15 \%)$.

\section{Measurement of $\mathrm{pH}$, fleigh points and lactic acid concentration}

Measurement of acidity degree $(\mathrm{pH})$ by using a pH meter (type 8010, Hanna Instruments). The concentration of lactic acid was determined by acid titration method (AOAC, 2005). Briefly, $50 \mathrm{mg}$ silage sample was taken from each treatment, added by distilled water $(50 \mathrm{ml})$, stirred homogeneously and allowed to stand for 5 minutes. The supernatant of samples was taken to measure $\mathrm{pH}$ and lactic acid concentration.

Fleigh points $(\mathrm{Fp})$ was calculated according to Kiliç (1984) as previously reported by Ozturk et al. (2006) with the following equation: $\mathrm{Fp}=220+[(2 \mathrm{x} \% \mathrm{DM})-$ 15] - [40 x pH], where DM denotes dry matter of silage. Silage quality is characterized as following very good (85-100), good (60-85), moderate (55-60), satisfying (25-55) and bad quality/worthless $(<25)$.

The concentration of lactic acid (crude) was measured by titimetry method according to AOAC (2005) as followed the equation:

$$
\% \mathrm{LA}=\frac{(\text { Vts }- \text { Vto }) \times \mathrm{N} \times \mathrm{MW} \times \mathrm{Df}}{\text { Vs } \times 1000} \times 100 \%
$$

Note:

LA = concentration of crude lactic acid

Vts $=$ volume of sample titrant $(\mathrm{ml})$

Vto = volume of blank titrant $(\mathrm{ml})$

$\mathrm{N}=$ normality of titrant $(\mathrm{NaOH})=0,1 \mathrm{~N}$

$\mathrm{MW}=$ molecular weight of lactic acid = $90,0(\mathrm{~g} / \mathrm{mol})$

$\mathrm{Df} \quad=$ dilution factor $=10 \mathrm{x}$

Vs $\quad$ volume of sample $(\mathrm{ml})$

\section{Palatability test of silage}

Silage palatability test was carried out by palatability test method as previous reported by Scharenberg et al. (2007) and Sofyan et al. (2007). Briefly, $500 \mathrm{~g}$ of fresh silage which was harvested at $21 \mathrm{~d}$ of incubation, was taken and fed to animal. Each sample was freely fed by animal with with the randomized sample position to minimize the bias of sample order (Figure 2).

Three Ongole crossbred cattles $(\mathrm{BW}=$ $224 \pm 8.39 \mathrm{~kg}$ ) that used in the palatability test were kept in the BPTBA-LIPI cattle barn. Prior to palatability test, animal was restricted by 


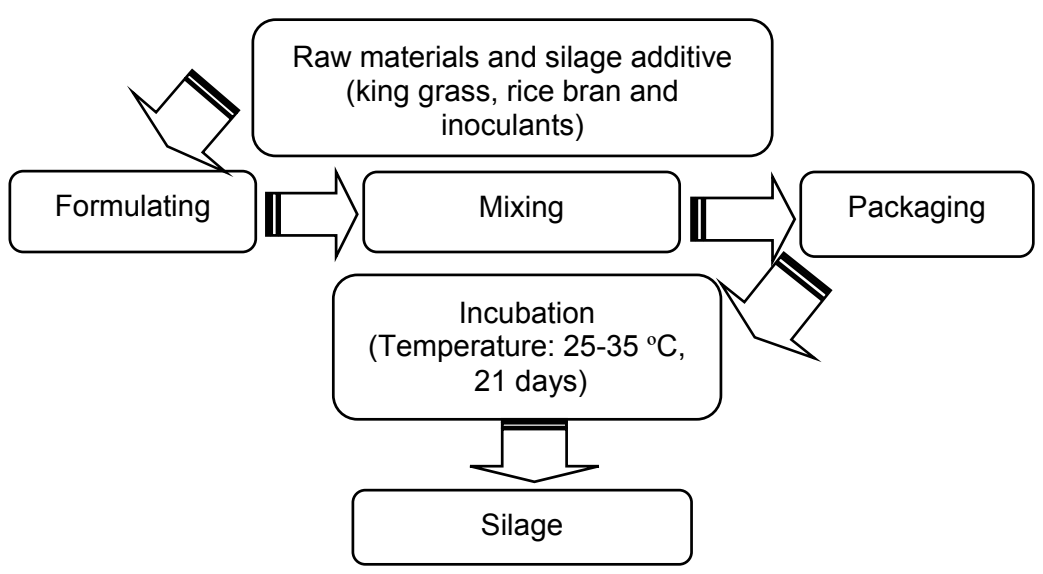

Figure 1. Flow chart in making silage

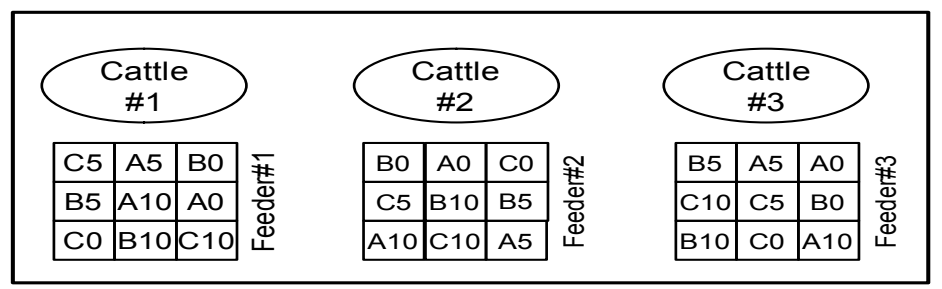

Figure 2. Illustration of randomized sample placed in silage feeder for evaluating palatability

feeding until 2 hours to reduce a satiation effect from the previous feeding.

Randomization of silage samples place for each treatment was carried out to reduce the bias of cow preference to certain samples. Silage palatability value was estimated from the percentage consumed cow silage samples for $10 \mathrm{~min}$ relative to the amount of the initial silage samples. Palatability value was calculated following the equation:

$$
\operatorname{PVi}(\%)=\frac{\mathrm{Si}}{\left(\mathrm{S}_{1}+\mathrm{S}_{2}+\mathrm{S}_{3}+\cdots+\mathrm{S}_{9}\right)} \times 100 \%
$$

Note:

$\mathrm{PVi}=$ palatability value of silage at treatment-

$$
\text { i (\%) }
$$

Si = consumed silage from treatment-i (g)

$\mathrm{l}=$ silage samples $(\mathrm{i}=1,2,3, \ldots, 9)$.

Code-i denote 1 (A0), 2 (A5), 3 (A10), 4 (B0), 5 (B5), 6 (B10), 7 (C0), 8 (C5), and 9 (C10).

\section{Data analysis}

Data of physical characteristics of silage were analyzed descriptively. Data of chemical characteristics, such as $\mathrm{pH}$, Fleigh points, crude lactic acid concentration and palatability of silage were analyzed by ANOVA (analysis of variance / ANOVA). If among the treatments showed significant differences at least 5\% $(P<0.05)$, then a post hoc of the orthogonal contrast test was applied (Gomez and Gomez, 2007). Interaction of silage characteristic and palatability was performed by linear regression. Raw data of Clostridia colonies that was reported by Sofyan et al. (2011a) were converted into logarithmic transformation then those were integrated in correlation analysis. A network analysis curve was applied to simplify the interaction of each parameter.

\section{Results and Discussion}

\section{Physicochemical characteristic of king grass silage}

Physical and chemical characteristic of king grass silage was evaluated to determine the effect of $L$. plantarum and $S$. cerevisiae inoculants consortia in combination with rice bran addition during $21 \mathrm{~d}$ incubation. The physical characteristic of silage was assessed by the texture color, flavor, and fungal contamination. Contamination was indicated by fungus colonies grown on silage. Silage was treated inoculants with/without rice bran addition showed more fragrant flavor than that in control silage in parallel with the 
addition of rice bran tended to improve silage flavor (Table 2).

The texture of all silage sample was similar in color i.e. green-browning. Although no observed fungal contamination, silage without inoculation and rice bran addition (control) showed the worst flavor compared with others. Fungal contamination tended to be higher in the silage added with rice bran, except for the silage treated $\mathrm{Lp}+\mathrm{Sc}$ with rice bran addition up to $5 \%$.

The addition of rice bran up to $10 \%$ seemed to be higher in fungal contamination. It might be relate to high starchy materials content (nitrogen free extract) in rice bran that were favorable for growing fungi and undesirable microorganism. However, the contamination could be reduced by adding $\mathrm{Lp}+\mathrm{Sc}$ inoculants combined with $5 \%$ of rice bran. Both of microbes in inoculants were previously reported that those had ability to produce antibacterial substances. In term, $L$. plantarum secretes bacteriocins substances (Thuault et al., 1991; Gollop et al., 2005; Valan-Arasu et al., 2013) and S. cerevisiae generates oxylipins (Strauss et al., 2005) that those affect Clostridia and fungi inhibition.

Besides physical characteristics, it was also performed an evaluation of chemical characteristics i.e. $\mathrm{pH}$, crude lactic acid and Fleigh points in the silage that those were presented in Table 3. Addition of inoculants significantly $(P<0.05)$ decreased $\mathrm{pH}$, and tended to increase concentration of crude lactic acid $(P=0.058)$ and Fleigh points $(P=$ $0.081)$. The addition of rice bran showed a significant increase of lactic acid and Fleigh points while $\mathrm{pH}$ seemed to decrease. The addition of silage with rice bran up to $10 \%$ increased the concentration of lactic acid significantly $(P<0.05)$. Silage treated with a combination of Lp+Sc showed the highest concentration of crude lactic acid $(11.59 \%)$.

Other study reported that concentration of lactic acid and $\mathrm{pH}$ in Italian ryegrass silage accounted for $8.51-10.44 \%$ DM and 3.933.97, respectively (Ridla and Uchida, 1999). In addition, Li et al. (2014) observed that king grass silage with addition of various WSC sources (molasses, sucrose and glucose) resulted in lactic acid and $\mathrm{pH}$ were 4.36$4.56 \%$ DM and 4.28-4.46, respectively. Compared to those studies, concentration of lactic acid of silage in this study tended to be higher than that in other studies. The measured crude lactic acid might consist of other organic acids (such as acetic acid) in small amount/concentration. Lactic acid $\left(\mathrm{pK}_{\mathrm{a}}\right.$ of 3.86) is a stronger acid than acetic acid ( $\mathrm{pK}_{\mathrm{a}}$ of 4.75) (Danner et al., 2003). Consequently, the measured pure lactic acid in silage implied in lower $\mathrm{pH}$ than the measured crude lactic acid (it possibly contained acetic acid).

High concentration of lactic acid was followed by reducing $\mathrm{pH}$. An increase of lactic acid indicated that soluble carbohydrate might support microbial growth in inoculants. Based on proximate analysis, rice bran was used in this experiment contained soluble fraction (NFE, nitrogen free extract) accounted for 30$35 \%$ (DM). Silage quality could be determined by indication of lactic acid concentration and $\mathrm{pH}$ values. Good quality of silage was determined if lactic acid content concentration reached $8-12 \%$ DM basis (Holmes and Brookes, 2008) with $\mathrm{pH}$ was no higher than 4.2 (McDonald et al., 1991). Based on data from Table 3, Fleigh points was ranges of 78.9 , in term the silage could be categorized as good quality. Santoso et al. (2009) revealed that king grass silage treated by inoculants had better quality than silage

Table 2. Physical characteristic of king grass silage treated by rice bran and inoculants consisting of $L$. plantarum (Lp) and S. cerevisiae (Sc)

\begin{tabular}{lllll}
\hline \hline \multirow{2}{*}{ Inoculants } & \multirow{2}{*}{ Variables } & \multicolumn{3}{c}{ Level of rice bran addition (\%WSC) } \\
\cline { 3 - 5 } & & \multicolumn{1}{c}{$0 \%(0.0 \%)$} & $5 \%(0.27 \%)$ & $10 \%(0.54 \%)$ \\
\hline \multirow{3}{*}{ Control } & Color & Green-browning & Green-browning & Green-browning \\
& Flavor & Slightly fragrant & Fragrant & Fragrant \\
& LFC & Not found & Slightly & Medium \\
\hline \multirow{3}{*}{$\mathrm{Lp}\left(10^{6} \mathrm{cfu} / \mathrm{g}\right)$} & Color & Green-browning & Green-browning & Green-browning \\
& Flavor & Heavily fragrant & Heavily fragrant & Heavily fragrant \\
& LFC & Slightly & Slightly & Medium \\
\hline $\mathrm{Lp}+\mathrm{Sc}$ & Color & Green-browning & Green-browning & Green-browning \\
$\left(10^{6} \mathrm{cfu} / \mathrm{g}[\mathrm{Lp}]+10^{5} \mathrm{cfu} / \mathrm{g}[\mathrm{Sc}]\right)$ & FFC & Heavily fragrant & Heavily fragrant & Heavily fragrant \\
\hline
\end{tabular}

$L F C=$ Level of fungal contamination . 
Table 3. Degree of acidity and Fleigh points of king grass silage treated by rice bran and inoculants consisting of L. plantarum (Lp) and S. cerevisiae (Sc)

\begin{tabular}{|c|c|c|c|c|}
\hline \multirow{2}{*}{$\begin{array}{c}\text { Inoculants } \\
\text { (CFU/g sample) }\end{array}$} & \multicolumn{3}{|c|}{ Level of rice bran addition (\% WSC) } & \multirow[b]{2}{*}{ Average } \\
\hline & $\begin{array}{c}0 \% \\
(0.0 \%)\end{array}$ & $\begin{array}{c}5 \% \\
(0.27 \%)\end{array}$ & $\begin{array}{c}10 \% \\
(0.54 \%)\end{array}$ & \\
\hline & \multicolumn{4}{|c|}{ - } \\
\hline Control & $4.34^{\mathrm{a}}$ & $4.28^{\mathrm{a}}$ & $4.34^{\mathrm{a}}$ & $4.32^{b}$ \\
\hline $\operatorname{Lp}\left(10^{6} \mathrm{cfu} / \mathrm{g}\right)$ & $4.31^{\mathrm{a}}$ & $4.24^{\mathrm{a}}$ & $4.24^{a}$ & $4.26^{b}$ \\
\hline Lp+Sc $\left(10^{6} \mathrm{cfu} / \mathrm{g}[\mathrm{Lp}]+10^{5} \mathrm{cfu} / \mathrm{g}[\mathrm{Sc}]\right)$ & $4.24^{a}$ & $4.10^{a}$ & $4.12^{\mathrm{a}}$ & $4.15^{\mathrm{a}}$ \\
\hline \multirow[t]{2}{*}{ Average } & $4.30^{\mathrm{a}}$ & $4.21^{\mathrm{a}}$ & $4.23^{\mathrm{a}}$ & \\
\hline & \multicolumn{4}{|c|}{ - } \\
\hline Control & $8.85^{a}$ & $10.03^{a}$ & $13.40^{\mathrm{a}}$ & $10.76^{a}$ \\
\hline $\operatorname{Lp}\left(10^{6} \mathrm{cfu} / \mathrm{g}\right)$ & $7.59^{a}$ & $9.17^{\mathrm{a}}$ & $12.33^{\mathrm{a}}$ & $9.70^{\mathrm{a}}$ \\
\hline Lp+Sc $\left(10^{6} \mathrm{cfu} / \mathrm{g}[\mathrm{Lp}]+10^{5} \mathrm{cfu} / \mathrm{g}[\mathrm{Sc}]\right)$ & $9.48^{\mathrm{a}}$ & $12.96^{\mathrm{a}}$ & $12.33^{\mathrm{a}}$ & $11.59^{a}$ \\
\hline \multirow[t]{2}{*}{ Average } & $8.64^{\mathrm{a}}$ & $10.72^{\mathrm{b}}$ & $12.69^{c}$ & \\
\hline & \multicolumn{4}{|c|}{ 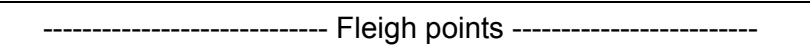 } \\
\hline Control & $70.76^{\mathrm{a}}$ & $81.25^{\mathrm{a}}$ & $78.81^{\mathrm{a}}$ & $76.94^{\mathrm{a}}$ \\
\hline $\operatorname{Lp}\left(10^{6} \mathrm{cfu} / \mathrm{g}\right)$ & $73.51^{\mathrm{a}}$ & $79.14^{\mathrm{a}}$ & $82.93^{\mathrm{a}}$ & $78.53^{\mathrm{a}}$ \\
\hline Lp+Sc $\left(10^{6} \mathrm{cfu} / \mathrm{g}[\mathrm{Lp}]+10^{5} \mathrm{cfu} / \mathrm{g}[\mathrm{Sc}]\right)$ & $72.76^{a}$ & $83.43^{a}$ & $88.01^{\mathrm{a}}$ & $81.40^{\mathrm{a}}$ \\
\hline Average & $72.35^{\mathrm{a}}$ & $81.27^{\mathrm{b}}$ & $83.25^{b}$ & \\
\hline
\end{tabular}

without inoculants (Fleigh points $=41.7$ vs 14.2).

\section{Palatability of silage}

The result of palatability test of silage to cattle is presented in Table 4. Silage treated with inoculation and rice bran addition was higher palatability than silage without inoculants (control).

The highest palatability (about 33\%) was observed in silage treated by $\mathrm{Lp}+\mathrm{Sc}$ insulation with/without the addition of rice bran. However, silage without treatments was not consumed by cattle (palatability $=0 \%$ ). The addition of silage inoculants improved the physical quality by improving silage flavor. In accordance with the physical parameters in Table 2, silage treated by inoculants had a better flavor characteristic than others.

Palatability is a favorite response to the consumed raw materials or animal feed (Grovum, 1988). Feed palatability involves feedstuffs characteristics that stimulate sensorial acceptance by olfactory, gustatory and tactile stimuli in animal (Scharenberg et al., 2007). The level of palatability of feedstuffs including silage was possibly influenced by taste, smell and texture of those materials. This result was reliable with previous study that silage treated by semiaerobic inoculants (Rhizopus sp. and $S$. cerevisiae) was more palatable than silage without inoculants (93\% vs $50 \%$ ) (Sofyan et al., 2007). High palatability of the inoculated silage was associated by their fragrant flavor that formed during ensilage. This volatile compound has contributed to fragrance formation in silage through involvement of enzymatic activity for synthesizing aromatic compound/flavoring substances in silage. Carrau et al. (2008) reported that aromatic compound i.e. esters, alcohols, acids and lactones as component of flavor in fermented products of grape juice can be produced by $S$. cerevisiae.

Parameter palatability affects consumption (intake) to meet dry matter and nutrients requirements. Baumont (1996) reported that palatability was highly correlated with the amount of feed consumed and affected the flow rate of feed in the digestive tract. In this study, the silage that treated by either inoculants treatment or rice bran addition improved the quality parameters i.e. physical, chemical and palatability silage to animal. Although similar in palatablity with the incoulant treated silage with rice bran addition, the inoculated silage added by rice bran had better physicochemical characteristics. Inoculation without addition of soluble carbohydrate source affected degradation of substrate in forage. Dry matter loss reached $1-9 \%$ during ensilage was frequently caused by damage of aerobic conditions (oxidation) (McDonald et al., 1991). By addition of WSC substances, dry matter 
Table 4. Palatability of silage inoculated by L. plantarum (Lp) and S. cerevisiae (Sc) with the addition of rice bran

\begin{tabular}{lcccr}
\hline \multirow{2}{*}{$\begin{array}{c}\text { Inoculants } \\
\text { (CFU/g sample) }\end{array}$} & \multicolumn{3}{c}{ Level of rice bran addition (\% WSC) } & \\
\cline { 2 - 3 } & $0 \%$ & $5 \%$ & $10 \%$ & Average \\
\hline & $(0.0 \%)$ & $(0.27 \%)$ & $(0.54 \%)$ & \\
Control & -0.00 & 1.67 & 18.33 & 6.67 \\
Lp $\left(10^{6} \mathrm{cfu} / \mathrm{g}\right)$ & 26.67 & 18.33 & 33.33 & 26.11 \\
$\mathrm{Lp}+\mathrm{Sc}\left(10^{6} \mathrm{cfu} / \mathrm{g}[\mathrm{Lp}]+10^{5} \mathrm{cfu} / \mathrm{g}[\mathrm{Sc}]\right)$ & 33.33 & 33.33 & 33.33 & 33.33 \\
\multicolumn{1}{c}{ Average } & 20.00 & 17.78 & 28.33 & \\
\hline
\end{tabular}

loss of forage can be minimized and lactic acid bacteria growth can be optimized. On the other hands, inoculants treatment without adequacy of WSC implied reducing in organic matter digestibility because most organic material degraded during ensilage although these physical qualities i.e. flavor and palatability were still improved.

\section{General discussion: interelationship of} silage characteristic and palatability

In order to evaluate interdependency between parameters, regression analysis was performed to assess correlation of each parameter (Figure 3). In this study, palatability of king grass silage was directly influenced by Clostridia colony and $\mathrm{pH}$, however, indirectly affected by Fleigh points and crude lactic acid concentration (Figure 4).

An increase of clostridia colony number possibly affected decrease of palatability. Clostridia in silage caused the breakdown of protein fractions into ammonia by proteolytic enzymes produced by Clostridia (McDonald et al., 1991), and able to convert lactic acid into butyric acid with the formation of hydrogen gas and carbon dioxide (Stefanie et al., 2000). Lalou et al. (2013) reported that S. cerevisiae is used an inoculant to ferment sugar and generate volatile compound i.e. $\beta$-pinene, $\beta$ terpineol, and D-limonene etc. These volatile substances are known as bio-flavor compounds. Indeed, DM of silage has also associated with Fleigh points (Ozturk et al., 2006). Other study reported that moisture content of silage affects microbial activity during ensilage (Weinberg and Muck, 1996). High moisture content in silage (more than $70 \%$ ) has a challenge for Clostridia growth. Silage with bad flavor might be occurred as consequence of clostridial deterioration (Mathews, 1999).

In addition, deterioration in silage was indicated by fungal contamination and badsilage flavor. Fungi and clostridia are easily growing on silage when anaerobic condition could not be achieved. Butyric acid producing bacteria such as clostridia in silage affected deterioration and off-flavor silage (Vissers et al., 2007). Lactic acid bacteria could be used as bio-preservative agent inhibit fungi growth. Valan-Arasu et al. (2013) observed antifungal compound from Lactobacillus plantarum KCC-10. Bacteriocins can be functioned as antifungal compound, which are secondary metabolites and serve to inhibit pathogenic bacteria such as Clostridia.

The inhibition of the growth of Clostridia, fungi and other undesirable microbes in silage treated by inoculants consisted of $L$. plantarum and $S$. cerevisiae is more due to the ability of $S$. cerevisiae to produce antibacterial substances. Yeast $S$. cerevisiae can produce oxylipin as antifungal substance which has a role in Clostridia inhibition (Strauss et al., 2005). The existence of an active compound supporting functions of bacteriocins produced by $L$. plantarum. Synergism of $L$. plantarum and S. cerevisiae in inhibiting the growth of Clostridia are indicated by the number of these colonies in the treated silage $\mathrm{Lp}+\mathrm{Sc}$ which tend to be lower than control and the Lp-treatment. The number of Clostridia colonies were lower in treated silage indicated that inoculated silage maintained the low level of deterioration.

Other study indicated that quality cocoa pod silage could be improved by the addition of Lp+Sc inoculant (Zakariah et al., 2016). Effectivity of yeast was also contributed in increasing rumen microbe population and short chain fatty acids (Riyanti et al., 2016). Improving nitrogen utilization and fiber digestion in the rumen of cattle by yeast $S$. cerevisiae supplementation were also reported by several studies (ChaucheyrasDurand et al., 2016; Ouellet and Chiquette, 2016).

Overall, the use of L. plantarum $\left(10^{6}\right.$ $\mathrm{cfu} / \mathrm{g})$ and $S$. cerevisiae $\left(10^{5} \mathrm{cfu} / \mathrm{g}\right)$ in combination with water soluble carbohydrate $(0.27-0.54 \%$ DM) had mutual effect to 
improve silage quality. Furthermore, aerobic deterioration and rotten silage caused by fungi and clostridial contamination can be presumbly prevented by applying those inoculation methods. Consequently, those ensilage methods ensure continuity of forage

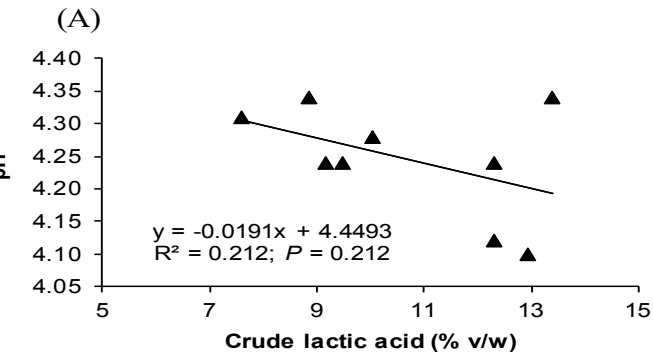

(C)

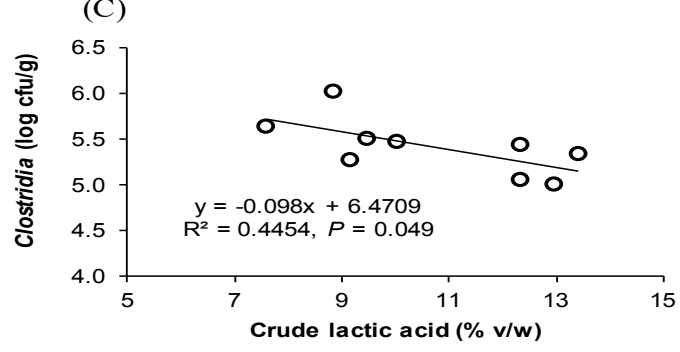

(E)

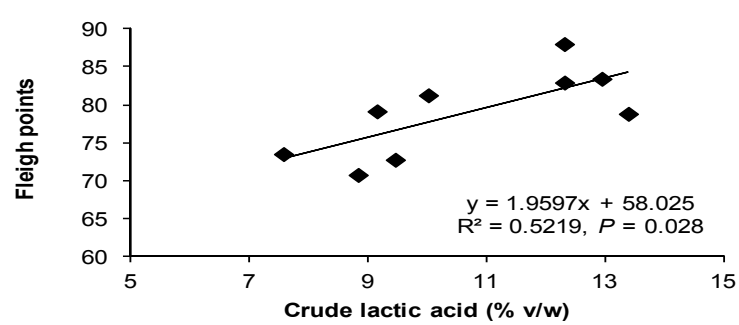

(G)
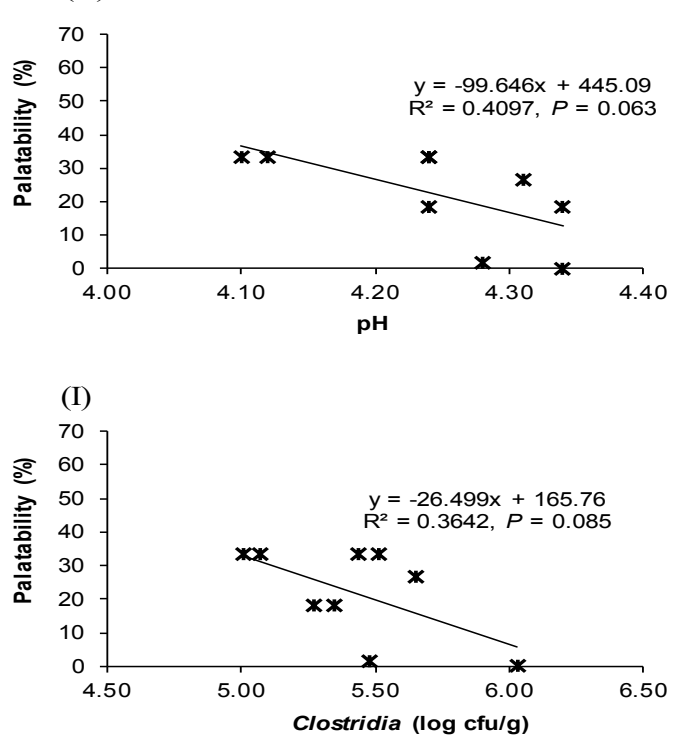

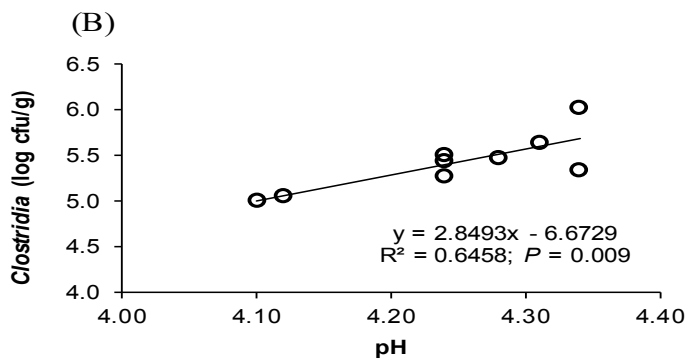

(D)
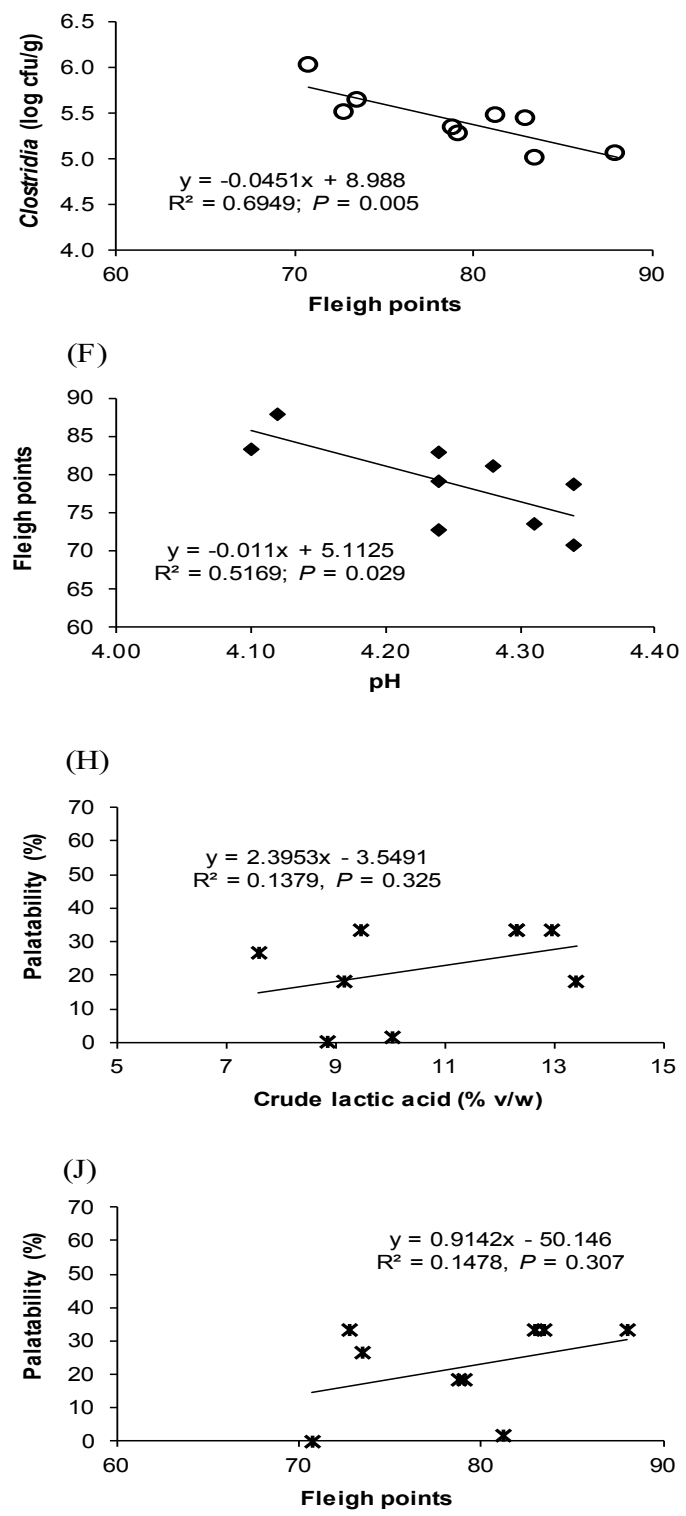

Figure 3. Interrelationship of physicochemical characteristics and palatability of king grass silage. 


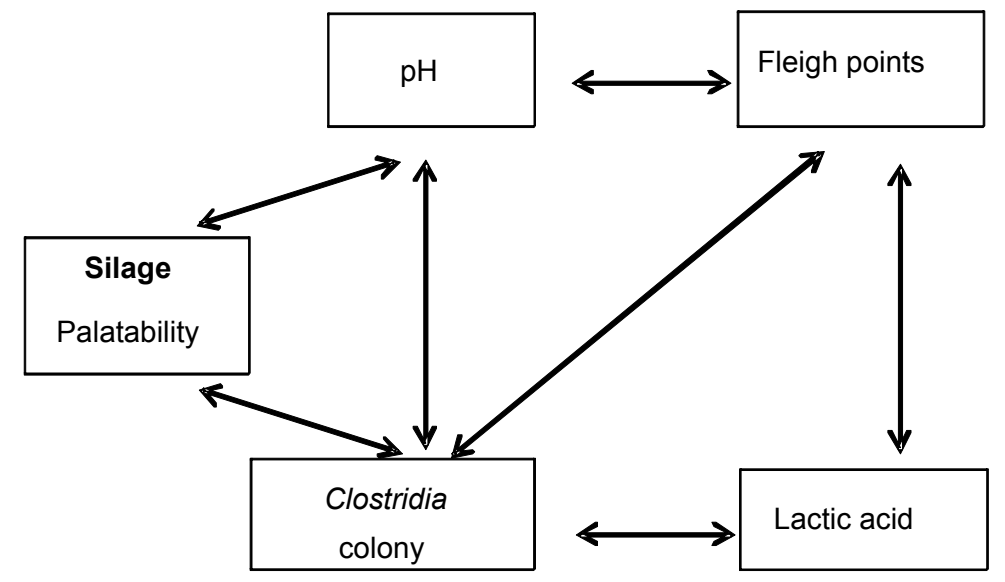

Figure 4. Network analysis chart visualized physicochemical characteristics that influenced palatability of king grass silage. Arrow connectors denote a significant correlation at least $(P<0.05)$.

preservation and economically advantage in ruminant production. Perhaps, further implementation of these ensilage technology could be easily adopted by either in smallholder farmers or livestock industrial scale.

\section{Conclusion}

The use of lactic acid bacteria inoculant ( $100 \%$ of L. plantarum) or in combination with S. cerevisiae $(75 \%$ of $L$. plantarum and $25 \%$ of S.cerevisiae) by adding a source of soluble carbohydrate (rice bran) improved the physicochemical quality and palatability of king grass silage.

\section{Acknowledgements}

The authors would like gratetfully appreciate to the Indonesian Ministry of Research, Technology and Higher Education (Kemenristekdikti) and the Research Unit for Natural Product Technology (BPTBA), the Indonesian Institute of Sciences (LIPI) for supporting the experiment.

\section{References}

Amer, S., F. Hassanat, R. Berthiaume, P. Seguin, and A. F. Mustafa. 2012. Effects of water soluble carbohydrate content on ensiling characteristics, chemical composition and in vitro gas production of forage millet and forage sorghum silages. Anim. Feed Sci. Technol. 177: 23-29.

AOAC. 2005. Official Method of Analysis. In: Association of Official Analytical
Chemists (AOAC). Helrich, K. (ed.) $15^{\text {th }}$ edn. Arlington, V.A.

Baumont, R. 1996. Palatability and feeding behavior in ruminants. A review. Ann. Zootech 45: 385-400.

Budiman, H. and S. Djamal. 1994. Hijauan Pakan Ternak. Pusat Perpustakaan Pertanian dan Komunikasi Penelitian, Badan Penelitian dan Pengembangan Pertanian, Bogor.

Carrau, F. M., K. Medina, L. Farina, E. Boido, P. A. Henschke, and E. Dellacassa. 2008. Production of fermentation aroma compounds by Saccharomyces cerevisiae wine yeasts: effects of yeast assimilable nitrogen on two model strains. FEMS Yeast Res. 8: 11961207.

Chaucheyras-Durand, F., A. Ameilbonne, A. Bichat, P. Mosoni, F. Ossa, and E. Forano. 2016. Live yeasts enhance fiber degradation in the cow rumen through an increase in plant substrate colonization by fibrinolytic bacteria and fungi. J. Appl. Microbiol. 120: 560-570.

Danner, H., M. Holzer, E. Mayrhuber, and R. Braun. 2003. Acetic acid increases stability of silage under aerobic conditions. Appl. Environ. Microb. 69: 562-567.

Despal, I. G. Permana, S. N. Safarina, and A. J. Tatra. 2011. Addition of water soluble carbohydrate sources prior to ensilage for ramie leaves silage qualities improvement. Media Peternakan 34: 69-76.

Duniere, L., L. Jin, B. Smiley, M. Qi, W. Rutherford, Y. Wang, and T. McAllister. 
2015. Impact of adding Saccharomyces strains on fermentation, aerobic stability, nutritive value, and select lactobacilli populations in corn silage. J. Anim. Sci. 93: 2322-2335.

Gobbetti, M. 1998. The sourdough microflora: interactions of lactic acid bacteria and yeasts. Trends Food Sci. Technol. 9: 267-274.

Gollop, N., V. Zakin, and Z. G. Weinberg. 2005. Antibacterial activity of lactic acid bacteria included in inoculants for silage and in silages treated with these inoculants. J. Appl. Microbiol. 98: 662666.

Gomez, K. A. dan A. A. Gomez. 2007. Prosedur Statistik untuk Penelitian Pertanian. Edisi Kedua. Terjemahan: E. Sjamsuddin dan J. S. Baharsjah. Penerbit Universitas Indonesia (UIPress), Jakarta.

Grovum, W. L. 1988. Appetite, palatability and control of feed intake. In: The Ruminant Animal Digestive Physiology and Nutrition. D. C. Church (Ed). A Reston Book Prentice Hall, Englewood Cliffs, New Jersey. pp. 202-216.

Holmes, C. W. and I. M. Brookes. 2008. What is high quality pasture silage? Farm Fact 1-46. https://www.dairynz.co.nz/ media/253723/1-46_What_is_high_ quality_silage.pdf. Accessed 18 January 2017.

International Committee for Animal Recording [ICAR]. 2010. Forage and Grasses. http://www.icar.org.in/files/forage-andgrasses.pdf. Accessed 2 January 2011.

Kiliç, A. 1984. Silo yemi (Silage Feed). Bilgehan Press, Izmir, Turkey. pp. 350.

Lalou, S., F. Mantzouridou, A. Paraskevopoulou, B. Bugarski, S. Levic, and V. Nedovic. 2013. Bioflavour production from orange peel hydrolysate using immobilized Saccharomyces cerevisiae. Appl. Microbial. Biotechnol. 97: 9397-9407.

Li, M., X. Zi, H. Zhou, G. Hou, and Y. Cai. 2014. Effects of sucrose, glucose, molasses and cellulase on fermentation quality and in vitro gas production of king grass silage. Anim. Feed Sci. Technol. 197: 206-212.

Mathews, M. C. 1999. Bad Smelling Silage. University of California Cooperative Extension. http://cestanislaus.ucanr. edu/files/111040.htm. Accessed 15 September 2016.

McDonald, P., A. R. Henderson, and S. J. E. Heron. 1991. The Biochemistry of silage. Second Edition. Chalcombe Publications, Marlow, UK.

Ouellet, D. R. and J. Chiquette. 2016. Effect of dietary metabolizable protein level and live yeasts on ruminal fermentation and nitrogen utilization in lactating dairy cows on a high red clover silage diet: yeast and metabolizable protein supply for cows. Anim. Feed Sci. Technol. 220: 73-82.

Ozturk, D., M. Kizilsimsek, A. Kamalak, O. Canbolat, and C. O. Ozkan. 2006. Effects of ensiling alfalfa with wholecrop maize on the chemical composition and nutritive value of silage mixtures. Asian Australas. J. Anim. Sci. 19: 526-532.

Ridla, M. and S. Uchida. 1999. Comparative study on the effects of combined treatments of lactic acid bacteria and cellulases on the fermentation characteristic and chemical composition of rhodesgrass (Chloris gayana Kunth.) and italian ryegrass (Lolium multiflorum Lam.) silages. Asian-Australas. J. Anim. Sci. 12: 525530.

Riyanti, L., Suryahadi, and D. Evvyernie. 2016. In vitro fermentation characteristics and rumen microbial population of diet supplemented with Saccharomyces cerevisiae and rumen microbe probiotics. Media Peternakan 39: $40-45$

Santos, E. M., T. C. Silva, C. H. O. Macedo, and F. S. Campos. 2013. Lactic acid bacteria in tropical grass silages. In: Lactic Acid Bacteria-R \& D for Food, Health and Livestock Purposes. M. Kongo (Ed). InTech Publisher, Croatia. pp. 335-362. http://www.doi.org/ $10.5772 / 2825$.

Santoso, B., B. T. Hariadi, H. Manik, dan H. Abubakar. 2009. Kualitas rumput unggul tropika hasil ensilase dengan bakteri asam laktat dari ekstrak rumput terfermentasi. Media Peternakan 32: 137-144.

Scharenberg, A., Y. Arrigo, A. Gutzwiller, C. R. Soliva, U. Wyss, M. Kreuzer, and F. Dohme. 2007. Palatability in sheep and in vitro nutritional value of dried and ensiled sainfoin (Onobrychis viciifolia) 
birdsfoot trefoil (Lotus corniculatus), and chicory (Cichorium intybus). Arch. Anim. Nutr. 61: 481-496.

Sofyan, A., H. Herdian, A. Febrisiantosa, and H. Julendra. 2007. The palatability of complete feed silage treated by semiaerobic inoculants. Proceeding of National Seminar "Asosiasi Ahli Nutrisi dan Pakan Indonesia (AINI) VI". Faculty of Animal Sciences, UGM-Yogyakarta, 26-27 July 2007. Pp. 416-421.

Sofyan, A., L. M. Yusiati, Y. Widyastuti, and R. Utomo. 2011a. Microbiological characteristic and fermentability of king grass (Pennisetum hybrid) silage treated by lactic acid bacteria yeast inoculants consortium combined with rice bran addition. J. Indones. Trop. Anim. Agric. 36: 265-272.

Sofyan, A., R. Utomo, L. M. Yusiati, and Y. Widyastuti. 2011b. Isolation and identification of lactic acid bacteria and Saccharomyces cerevisiae from natural sources as feed-silage inoculants. Proceeding of the 3rd International Conference of Indonesian Society for Lactic Acid Bacteria. Yogyakarta, 21-22 January 2011.

Stefanie, J. W. H., O. Elferink, F. Driehuis, J. C. Gottschal, and S. F. Spoelstra. 2000. Silage Fermentation and Their Manipulation. In: Proc. of the FAO Electronic Conference on Tropical Silage. L.'t Mannetje (ed). September 1- December 15. Pp. 17-30.

Strauss, C. J., J. L. F. Kock, P. W. J. van Wyk, E. J. Lodolo, C. H. Pohl, and P. J. Botes. 2005. Bioactive oxylipins in Saccharomyces cerevisiae. J. Inst. Brew. 111: 304-308.

Tabacco, E., F. Righi, A. Quarantelli, and G. Borreani. 2011. Dry matter and nutritional losses during aerobic deterioration of corn and sorghum silages as influenced by different lactic acid bacteria inocula. J. Dairy Sci. 94: 1409-1419.
Thuault, D., E. Beliard, J. L. Guern, and C. M. Bourgeois. 1991. Inhibition of Clostridium tyrobutyricum by bacteriocin-like substances produced by lactic acid bacteria. J. Dairy Sci. 74 : 1145-1150.

Valan-Arasu, M., M. W. Jung, S. Ilavenil, M. Jane, D. H. Kim, K. D. Lee, H. S. Park, T. Y. Hur, G. J. Choi, Y. C. Lim, N. A. Al-Dhabi, and K. C. Choi. 2013. Isolation and characterization of antifungal compound from Lactobacillus plantarum KCC-10 from forage silage with potential beneficial properties. J. Appl. Microbiol. 115: 1172-1185.

Vissers, M. M. M., F. Driehuis, M. C. TeGiffel, P. De Jong, and J. M. G. Lankveld. 2007. Concentrations of butyric acid bacteria spores in silage and relationships with aerobic deterioration. J. Dairy Sci. 90: 928-936.

Weinberg, Z. G. and R. E. Muck. 1996. New trends and opportunities in the development and use of inoculants for silage. FEMS Microbiol. Rev.19: 53-68.

Zakariah, M. A., R. Utomo, and Z. Bachruddin. 2016. The effect of Lactobacillus plantarum and Saccharomyces cerevisiae culture addition prior to ensilage on in vitro fermentation and digestibility of cocoa pod silage. Bull. Anim. Sci. 40: 124-132.

Zhang, J. G., Y. Cai, R. Kobayashi, and S. Kumai. 2000. Characteristics of lactic acid bacteria isolated from forage crops and their effects on silage fermentation. J. Sci. Food Agric. 80: 1455-1460. 